\title{
Environmental risk assessment of metal-contaminated areas using different bioassays
}

\author{
Ol'ga Šestinová ${ }^{\bowtie}$, Jozef Hančulák and Lenka Findoráková \\ Department of Environment and Hygiene in Mining, Institute of Geotechnics, Slovak Academy of Sciences, Watsonova 45, \\ Košice 04001, Slovak Republic
}

\section{Article info}

\section{Article history:}

Received: $2^{\text {nd }}$ September 2020

Accepted: $25^{\text {th }}$ October 2020

\section{Keywords:}

Avoidance bioassays

Heavy metals

Phytotoxkit

Soils

Toxicity

\begin{abstract}
Mining activities in the areas Krompachy and Rudňany-Markušovce were focused on mining and processing of copper and mercury ore and left harmful effects on the region of Eastern Slovakia. The aim of this study is using different screening methods (XRF, Phytotoxkit and earthworm bioassays) for environmental risk assessment of metal-contaminated areas. Elemental analysis by X-ray fluorescence spectrometry indicated severe pollution of studied soils by $\mathrm{Cu}, \mathrm{Ni}, \mathrm{As}$ and $\mathrm{Hg}$, which exceeded limit values. Significant positive correlation is found between $\mathrm{Pb}$ and $\mathrm{Zn}$ occurrence in the agricultural soil from Krompachy: Kluknava, and for the contents of particular metals in soil from permanent grass vegetation in Kolinovce locality, namely between $\mathrm{Pb}$ and $\mathrm{Ni}, \mathrm{Pb}$ and $\mathrm{Zn}$, and between $\mathrm{Hg}$ and $\mathrm{Zn}$ contents. A 7-day bioassay and avoidance test with the Dendrobaena veneta was used to assess the environmental risk of heavy metals in soils. The earthworms mortality was very little influenced by metals in Krompachy soils, but rather affected by Rudňany soils tailing. Phytotoxkit results for soils from Krompachy showed inhibition in germination by $32 \%$ and $29 \%$ for Sinapis alba and Lepidium sativum, respectively. Results of the average percentage of growth inhibition by Lepidium sativum was $28 \%$ and $24 \%$ for Sinapis alba. On the other hand, soil samples from Rudňany tailing showed $56 \%$ of germination inhibition by Sinapis alba, and $49 \%$ for Lepidium sativum, respectively. Results of the average percentage of grow the inhibition by Lepidium sativum was $48 \%$, and $52 \%$ for Sinapis alba Rudňany tailing soils. The significant results $(P<0.05)$ of the avoidance percentages of Dendrobaena veneta for tested soils were within the range $80-100 \%$ in soils Rudňany-Markušovce tailing after $48 \mathrm{~h}$. The variable toxicity of contaminated soils demonstrated the efficiency and usefulness of the Phytotoxkit and earthworm bioassays as a useful tool for evaluation of soil ecotoxicity. The results supported the expected negative impact of the soil samples on the region Eastern Slovakia.
\end{abstract}

(C) University of SS. Cyril and Methodius in Trnava

\section{Introduction}

Soil is a dynamic and complex system that provides a habitat for different microorganisms, flora, animals, and humans. These days' soils are exposed to anthropogenic contamination with heavy metals that create a risk in many ecosystems as well as human health. Slovakia is note due to metal ore mines and their processing. The soil chemical reduction by heavy metal contamination, especially in Eastern Slovakia is an actual issue of societal matter. From the occurrence point of view of ores and industrial mining, it is one of the most significant geological formations 
in Slovakia (Demková et al. 2017; Maity et al. 2018; Šestinová et al. 2019a). Mining activities in the region Eastern Slovakia, Krompachy and Rudňany-Markušovce are focusing on copper and mercury ore mining and processing. Hence, the determination of the total heavy metal matter is not adequate to score the environmental problem, which is inseparable to a contaminated soil. For assessment of soil quality, bioassays could be effective tools to scale the potential contaminants toxicity aimed at bioavailability fraction (HundRinke et al. 2003; Loureiro et al. 2005; Šestinová et al. 2019c). Phytotoxkit (Phytotoxkit 2004) is an alternative test procedure which is giving estimation of the chemical compounds biological effects on plants.

Phytotoxicity bioassays with a higher plant collated on seed germination and root elongation growth measurements were conducted with different terrestrial plant species (Wang 1991; GarciaLorenzo et al. 2009). Data on phytotoxicity studies were thought over the toxicity evaluation of trade chemicals (Günter and Pestemer 1990), industrial effluents, dangerous wastes, and leachates (Vasseur et al. 1998; Czerniawska-Kusza and Kusza 2011). Recently, phytotoxicity tests with terrestrial plants are accepting increasing attention also in assessing soil toxicity. Given to its shortexposure periods and its high sensitivity, macrobiotics was successfully used as appropriate help for screening; hence they contribute to a responsible risk assessment for soil environments (Persoone et al. 2003). Earthworms are commonly used as model organisms to evaluate the ecological risk of various pollutants on soil ecosystems since are considered as fundamental organisms for proper soil functionality (Aldaya et al. 2006; Latha and Basha 2019).Furthermore, as major agents of the soil fauna biomass they contribute to soil aeration and drainage (Davies et al. 2003) as well as decomposition of organic matter that can be reduced as a consequence of pollution. Ability of organisms to evade contaminated soils serves as an indicator of soil ecotoxicity. Nannoni et al. (2014) has reported on variable bioconcentration of metal trace elements in earthworms at urban, peri-urban and garden levels depending on extent of pollution. Avoidance tests performed on soils from contaminated sites usually score and the response of organisms to a combination of different soil properties (e.g. structure, content of organic matter) with the effects of the contaminants. Soil properties outside the range of physiological requirements of the test species strongly influence the avoidance response to pollutants. Avoidance tests with most abundant soil organisms can be used as an early screening tool assessment. This study is devoted to evaluate the environmental risk in study soils using tests of ecotoxicity, Phytotoxkit microbiotest, earthworm acute toxicity and avoidance tests. The presented approach contributes to the future resolution of a local pollution problem in metalcontaminated environments.

\section{Experimental}

\section{Samples and analysis}

Soils were collected from two areas Krompachy (KR) and Rudňany-Markušovce (RM). Mining activities by the metallurgical treatment of complex metals and copper ores left negative effects on the region Eastern Slovakia, Krompachy and Rudňany- Markušovce tailing (Angelovičová et al. 2015; Šestinová et al. 2019a). The Markušovce tailing is situated between the Markušovce and Rudňany villages (SpišskoGemerské Rudohorie Mountains). Its construction and operation are connected with former and current mining activities on the Rudnany and Poráš-Zlatník polymetallic ore deposits. The thickness of deposited materials varies in the dependence on initial ground levels and it may achieve maximally about $38 \mathrm{~m}^{3}$. Recently, the settling pit is in operation by the SABAR, Ltd. Markušovce. Altogether 9800,000 tons of the tailings of so-called flotation sands at the density of $1.59 \mathrm{t} . \mathrm{m}^{-3}$ and a total volume of $6200,000 \mathrm{~m}^{3}$ are deposited in the settling pit (Jakabský et al. 2010; Hredzák et al. 2019). In the year 2015, the two sampling sites were localised in the surrounding Krompachy town sampled were agricultural soil in Kluknava: (KRAS) and permanent grass vegetation soil in Kolinovce: (KR- PGVS). The soils were collected from a depth of $20-40 \mathrm{~cm}$ into bags. Soils were homogenized, dried at room temperature, and sieved through 2-mm sieve 
(weight $5 \mathrm{~kg}$ ). Trough X-ray fluorescence spectrometer model XEPOS 3 the concentrations of $\mathrm{Cu}, \mathrm{Zn}, \mathrm{Ni}, \mathrm{Pb}$, As and $\mathrm{Hg}$ in soils and control reference soil (CRM-TM52) were measured. All the analyzed samples were conducted in triplicate.

\section{Soil phytotoxicity}

Evaluation of soil phytotoxicity was based on germination and seedling growth of the two terrestrial plants (mustard Sinapis alba and garden cress Lepidium sativum), by use the Phytotoxkit microbiotest (OECD 208). The soil was covered by the filter plate and after that seeds of the plant were placed on top of the filter in a single row. The test plates with the cover, they were placed vertically and incubated for $72 \mathrm{~h}$ at $25^{\circ} \mathrm{C}$. Five replicates were performed for the sample set. Root growth inhibition was measured after $72 \mathrm{~h}$. The test was considered to be valid if the number of germinated seeds in the control which was at least $90 \%$. Pictures of the test plates were analyzed through the program Image Tools. The percent inhibition of seed germination (ISG) and inhibition of root growth (IRG) for the plant were calculated using (Eq. 1):

$$
I S G(I R G)=\frac{\mathrm{A}-\mathrm{B}}{\mathrm{A}} \times 100
$$

where $A$ is the mean seed germination or root length in the control $(\mathrm{mm})$; and $B$ is the mean seed germination or root length in the test soil $(\mathrm{mm})$.

The system of toxicity classification generated by Persoone et al. 2003 was used to forecast the soil toxicity: PE (percent toxic effect) $<20 \%$, no significant toxic effect, class I, no acute hazard; $20 \%<\mathrm{PE}<50 \%$ significant toxic effect, low toxic sample, class II, low acute hazard; $50 \%<\mathrm{PE}$ $<100 \%$ significant toxic effect, toxic sample, class III, acute hazard; PE-100 \% (single test), class IV, high acute hazard; PE-100 \% (all tests), class V, very high acute hazard.

\section{Acute bioassays with Dendrobaena veneta}

The acute bioassays were based on Earthworm acute toxicity tests, (OECD 207). From a local supplier adult earthworms were purchased. Ten earthworms (and C.W. - control worms) were placed to a plastic box $(9 \mathrm{~cm} \times 9 \mathrm{~cm} \times 3 \mathrm{~cm})$ control worms were added to $100 \mathrm{~g}$ of CRM soil. Distilled water was added and the boxes were maintained at laboratory temperature for $7 \mathrm{~d}$. Earthworms' mortality for each soil was estimated and compared with corresponding control. Finally, the earthworms were lyophilized; the samples were mineralized and analyzed by atomic absorption spectrometry (AAS Variant, Australia) to determine the metals concentrations in warm tissues (Šestinová et al. 2019b).

\section{Avoidance bioassays with Dendrobaena veneta}

The avoidance tests with earthworms were based on ISO guideline 17512-1/2008 - Avoidance test for determining the quality of soils and effects of chemicals on behaviour: Test with the earthworms. Every replicate was composed of a plastic box: $23 \mathrm{~cm} \times 13 \mathrm{~cm} \times 6 \mathrm{~cm}$. The box was distributed into two parts by a divider. Every part was filled with $250 \mathrm{~g}$ dry weight of one of the three test soils (KR-AS, KR-PGV, RM) and a control soil (CRM) on the opposite. Later, the divider was eliminated and 10 adult earthworms were located onto the middle line. The test containers were over casted by a plastic wrap perforated with pinholes to facilitate air exchange. The test containers were incubated at $20 \pm 2{ }^{\circ} \mathrm{C}$ and a $16: 8 \mathrm{~h}$ light : dark photoperiod for $48 \mathrm{~h}$. Subsequently, the vessels were divided again with the divider at the end of the period, and the earthworms were counted on each side of the replicates. In the midline of the test container an earthworm found was counted as 0.5 earthworms. Earthworms found on the underside of the lid of the test were counted as dead. Soil pH was measured at the beginning and the end of the test period. The avoidance rates of worms to different soils were calculated according to Eq. 2, and expressed as a percentage:

$$
R(\%)=\frac{[(C-T)]}{N} \times 100
$$

where $R=$ avoidance; $\mathrm{C}=$ number of worms in the control $\left(C_{0}\right)$ condition; $T=$ number of worms in each dose in the same soil; $N=$ total number of worms. Positive values account for avoidance of worms in test soil, while neutral or negative responses represent indifference or preference of the test substance (Hund-Rinke et al. 2003). 
Table 1. Basic properties of analyzed soils samples from agricultural (KR-AS) and permanent grass vegetation soils in Krompachy (KR-PGVS), and from Rudňany-Markušovce (RM).

\begin{tabular}{lrrr}
\hline & \multicolumn{3}{c}{ Soils } \\
\cline { 2 - 4 } & KR-AS & KR-PGVS & RM \\
\hline $\mathrm{pH} / \mathrm{H}_{2} \mathrm{O}$ & 6.5 & 6.9 & 8.1 \\
$\mathrm{pH} / \mathrm{KCl}$ & 5.2 & 7.2 & 7.8 \\
$\mathrm{Eh} \mathrm{[mV]}$ & 582 & 580 & 686 \\
Dry weight [\%] & 97.9 & 94.3 & 99.6 \\
Organic matter dry weight [\%] & 5.6 & 7.3 & 9.8 \\
\hline Grain size [\%] & & & \\
\hline Sand & 3.7 & 4.5 & 4.2 \\
Silt & 30.2 & 24.7 & 27.2 \\
Clay & 66.1 & 70.8 & 68.6 \\
\hline
\end{tabular}

Dry weight (STN EN 75791), Organic matter dry weight (STN EN 12879).

\section{Statistical analysis}

Statistical analyses were done through SPSS ver. 9.0 software. By the Pearson matrix correlation the statistical dependence between total metal concentrations was evaluated. Correlation analysis was used as a comparison of the potential relationships among the data. The certified river sediment (LGC6187) was used to validate data. Control earthworms (CRM) fended in noncontaminated soil was used.

\section{Results and Discussion}

Soil physical and chemical properties, including grain size of the studied soils, are presented in Table 1. We recorded acidic $\mathrm{pH}$ values for the soil samples (KR-AS), near-neutral $\mathrm{pH}$ values for the soils from KR-PGVS and near-alkaline $\mathrm{pH}$ values for the soil samples from RM. The organic matter dry weight of all soils ranged between 5.6 to $9.8 \%$. The soil organic matters content could reduce metal concentrations in soil solution, and then, their potential availability and toxicity to earthworms (Lukkari et al. 2006; Šestinová et al. 2019b). All soil samples included the sand, silt and many clay fractions $(66.1-70.8)$. Soil types were silty-clay texture for all soil samples. Some studies have demonstrated that variations on $\mathrm{pH}$, electric conductivity, salinity, redox potential, cation exchange capacity (CEC), clay minerals, texture, permeability, porosity and moisture content influence the behaviour of metals in soil
(Das et al. 2011; Angelovičová et al. 2015; Šstinová et al. 2019a). Due to the heavy metal limits in the Slovakia soils (Law No. 220/2004), we found quite extensive contamination with $\mathrm{Cu}, \mathrm{Hg}$, $\mathrm{As}$, and $\mathrm{Ni}$ in all studied localities (KR-AS, KRPGVS and RM) (Table 2). It was found that after 7-days exposure, earthworms in some instances caused decrease of metal concentrations in contaminated soils; such drop was estimated between $5-20 \%$ for $\mathrm{Cu}, 4-19 \%$ for $\mathrm{Hg}, 5-$ $17 \%$ for As, $4-15 \%$ for $\mathrm{Pb}, 7-14 \%$ for $\mathrm{Ni}$ and $2-11 \%$ for $\mathrm{Zn}$, for all studied soils. Most processes, including direct dumping of wastes from ore extraction and manufacturing, may bring heavy metals into the surface soil. Usually, soil properties determine the bioavailability of toxic heavy metals (Šestinová et al. 2017; Maity et al. 2018; Bravo et al. 2019).

Acute toxicity tests results and the metals concentrations of the $D$. veneta tissue are demonstrated in Table 2. The earthworms mortality (n) was little effected by Krompachy soils, and rather influenced by Rudňany tailing soils. The higher pollutant concentrations (heavy metals) may be evaluated by the acute test, which propose dose-dependent effects on mortality. Less polluted soils require for reliable risk assessment more sensitive assays such as behavioral tests (Avoidance bioassays).

Pearson correlation analysis among heavy metals in the soils is demonstrated in Table 3. Statistical correlations at the levels $P<0.05$ and $\mathrm{P}<0.01$ were considered significant. Significant positive correlation was founded between $\mathrm{Pb}$ and $\mathrm{Zn}$ $(r=0.68, P<0.05)$ in the KR-AS soil, for the KR-PGVS soil was found between $\mathrm{Pb}$ and $\mathrm{Ni}$ $(r=0.86, P<0.05), \mathrm{Pb}$ and $\mathrm{Zn}(r=0.66, P<0.05)$, and $\mathrm{Hg}$ and $\mathrm{Zn}(r=0.79, P<0.05)$ (Table 3$)$. Significant positive correlation was identified among As and $\mathrm{Zn}(r=0.90, P<0.05)$ and $\mathrm{Hg}$ and $\mathrm{Pb}(r=0.65, P<0.05)$ for the RM-tailing soil (Table 3). Significant correlation was not be identified for As in the Krompachy soils (KR-AS and KR-PGVS). To know the heavy metals source the correlation analysis is a suitable way. Many authors dealing with the Eastern Slovakia environmental pollution has founded that the soil environment contamination by arsenic is related not only to anthropogenic impact but also to 
Table 2. Heavy metal content and corresponding worm mortality $(n)$ in soils from the region of Eastern Slovakia (average \pm standard deviation).

\begin{tabular}{|c|c|c|c|c|c|c|c|}
\hline \multirow[b]{2}{*}{ Locality } & \multicolumn{7}{|c|}{ Metal concentration in soils } \\
\hline & $\begin{array}{l}\mathrm{Cu} \\
{\left[\mathrm{mg} \cdot \mathrm{kg}^{-1}\right]}\end{array}$ & $\begin{array}{l}\mathrm{Zn} \\
{\left[\mathrm{mg} \mathrm{kg}^{-1}\right]}\end{array}$ & $\begin{array}{l}\mathrm{Ni} \\
{\left[\mathrm{mg}^{\prime} \mathrm{kg}^{-1}\right]}\end{array}$ & $\begin{array}{l}\mathrm{Pb} \\
{\left[\mathrm{mg} \mathrm{kg}^{-1}\right]}\end{array}$ & $\begin{array}{l}\text { As } \\
{\left[\mathrm{mg} \cdot \mathrm{kg}^{-1}\right]}\end{array}$ & $\begin{array}{l}\mathrm{Hg} \\
{\left[\mathrm{mg}^{\prime} \mathrm{kg}^{-1}\right]}\end{array}$ & $\begin{array}{l}\text { Mortality } \\
{[\%]}\end{array}$ \\
\hline \multicolumn{8}{|c|}{ No treatment } \\
\hline KR-AS & $172 \pm 56$ & $220 \pm 54$ & $62 \pm 14$ & $75 \pm 25$ & $50 \pm 12$ & $3.2 \pm 1.0$ & - \\
\hline KR-PGVS & $325 \pm 74$ & $478 \pm 82$ & $81 \pm 14$ & $109 \pm 9$ & $75 \pm 19$ & $20.4 \pm 2.5$ & - \\
\hline $\mathrm{RM}$ & $634 \pm 98$ & $35 \pm 15$ & $98 \pm 21$ & $31 \pm 5$ & $104 \pm 28$ & $82.5 \pm 8.1$ & - \\
\hline CRM & $3.2 \pm 4.0$ & $6.5 \pm 5.0$ & $11 \pm 2$ & $26 \pm 8$ & $1.4 \pm 1.0$ & $0.1 \pm 0.0$ & - \\
\hline \multicolumn{8}{|c|}{ Metal concentration in soils after 7-days bioassay } \\
\hline KR-AS & $156 \pm 49$ & $215 \pm 36$ & $53.2 \pm 8.0$ & $71.5 \pm 19$ & $46 \pm 6$ & $2.61 \pm 1.71$ & $n=2$ \\
\hline KR-PGVS & $309 \pm 30$ & $452 \pm 62$ & $75 \pm 15$ & $104 \pm 11$ & $71 \pm 13$ & $18.5 \pm 1.0$ & $n=4$ \\
\hline RM & $511 \pm 99$ & $31 \pm 10$ & $91 \pm 21$ & $26.5 \pm 3.0$ & $86.5 \pm 19.0$ & $79.2 \pm 0.1$ & $n=6$ \\
\hline CRM & $2.8 \pm 1.0$ & $6.0 \pm 2.0$ & $12 \pm 4$ & $24 \pm 3$ & $0.9 \pm 1$ & $0.10 \pm 0.01$ & $n=1$ \\
\hline \multicolumn{8}{|c|}{ Metal concentration in D. veneta tissues/7-days } \\
\hline KR-AS & $12.1 \pm 15$ & $102.5 \pm 17.5$ & $2.4 \pm 1.1$ & $7.8 \pm 9.5$ & $6.3 \pm 2.1$ & $0.12 \pm 0.03$ & - \\
\hline KR-PGVS & $17.1 \pm 10.0$ & $122 \pm 19$ & $2.6 \pm 1.3$ & $5.6 \pm 1.6$ & $7.6 \pm 2.5$ & $0.54 \pm 0.35$ & - \\
\hline RM & $24.7 \pm 21$ & $105 \pm 11$ & $19.1 \pm 11.5$ & $14.2 \pm 4.2$ & $5.2 \pm 1.9$ & $2.27 \pm 1.15$ & - \\
\hline C. W. & $4.3 \pm 2$ & $1.5 \pm 1.2$ & $2.1 \pm 0.8$ & $2.4 \pm 0.2$ & $0.4 \pm 0.0$ & $0.47 \pm 0.10$ & - \\
\hline Limit & 70 & 200 & 60 & 115 & 30 & 0.75 & - \\
\hline
\end{tabular}

KR-AS - agricultural soil and KR-PGVS - soils from permanent grass vegetation both from Krompachy, tailing in RudňanyMarkušovce; Control reference material - CRM; Law No. 220/2004 - Limit; Control worm - C.W.

the geochemical effects of mineralized zones (Hronec et al. 2008; Kučerová et. al. 2014; Angelovičová et al. 2015; Demková et al. 2017).

The individual heavy metals presence is caused by mining and smelting activities, as confirmed by significant positive correlations.

Table 3. Correlation relationship between heavy metals in soils from studied localities.

\begin{tabular}{|c|c|c|c|c|c|}
\hline & $\mathbf{Z n}$ & $\mathbf{N i}$ & $\mathbf{P b}$ & As & Hg \\
\hline \multicolumn{6}{|c|}{ Agricultural soil: Krompachy } \\
\hline $\mathrm{Cu}$ & 0.072 & -0.37 & 0.2 & 0.3 & 0.06 \\
\hline $\mathrm{Zn}$ & & 0.37 & 0.68 & -0.31 & 0.09 \\
\hline $\mathrm{Ni}$ & & & -0.08 & 0.16 & 0.22 \\
\hline $\mathrm{Pb}$ & & & & -0.73 & 0.6 \\
\hline As & & & & & -0.71 \\
\hline \multicolumn{6}{|c|}{ Permanent grass vegetation soil: Krompachy } \\
\hline $\mathrm{Cu}$ & -0.37 & 0.16 & 0.059 & -0.33 & -0.39 \\
\hline $\mathrm{Zn}$ & & 0.57 & 0.66 & 0.25 & 0.79 \\
\hline $\mathrm{Ni}$ & & & 0.86 & 0.39 & -0.007 \\
\hline $\mathrm{Pb}$ & & & & -0.01 & 0.22 \\
\hline As & & & & & -0.16 \\
\hline \multicolumn{6}{|c|}{ Tailing soil: Rudňany-Markušovce } \\
\hline $\mathrm{Cu}$ & 0.41 & -0.42 & -0.71 & 0.43 & -0.22 \\
\hline $\mathrm{Zn}$ & & -0.86 & -0.16 & 0.9 & -0.09 \\
\hline $\mathrm{Ni}$ & & & 0.18 & -0.83 & 0.35 \\
\hline $\mathrm{Pb}$ & & & & -0.26 & 0.65 \\
\hline As & & & & & -0.4 \\
\hline
\end{tabular}

Impact on plant performance was further tested. Phytotoxkit results for soils from Krompachy showed inhibition in germination by $32 \%$ and $29 \%$ for Sinapis alba and Lepidium sativum, respectively (Fig. 1). Results of the growth inhibition average percentage by Lepidium sativum was $28 \%$, and $24 \%$ for Sinapis alba. On the other hand, soil samples from Rudňany tailing showed $56 \%$ of germination inhibition by Sinapis alba, and $49 \%$ for Lepidium sativum. Results of the growth inhibition average percentage by Lepidium sativum revealed $48 \%$ and $52 \%$ for Sinapis alba for Rudňany tailing soils, see in Fig. 2. Soils of the RM-tailing have high As (104 mg. $\mathrm{kg}^{-1}$ ) and $\mathrm{Hg}$ (82 mg. $\left.\mathrm{kg}^{-1}\right)$ contents. The growth inhibition average percentage for L. sativum was $28 \%, 24 \%$ for $S$. alba in the two soils studied from the Krompachy area, as shown in Fig. 2.

The growth inhibition results showed that the potential toxicity is lower for the Krompachy soils. RM-tailing showed growth inhibition percentage lower than $50 \%$ and the values are lower than those for germination inhibition. Many agents that might have an impact on this plant response are present. The elements with similar physicochemical properties might interfere in enzymatic pathways, compete during transport and affect 


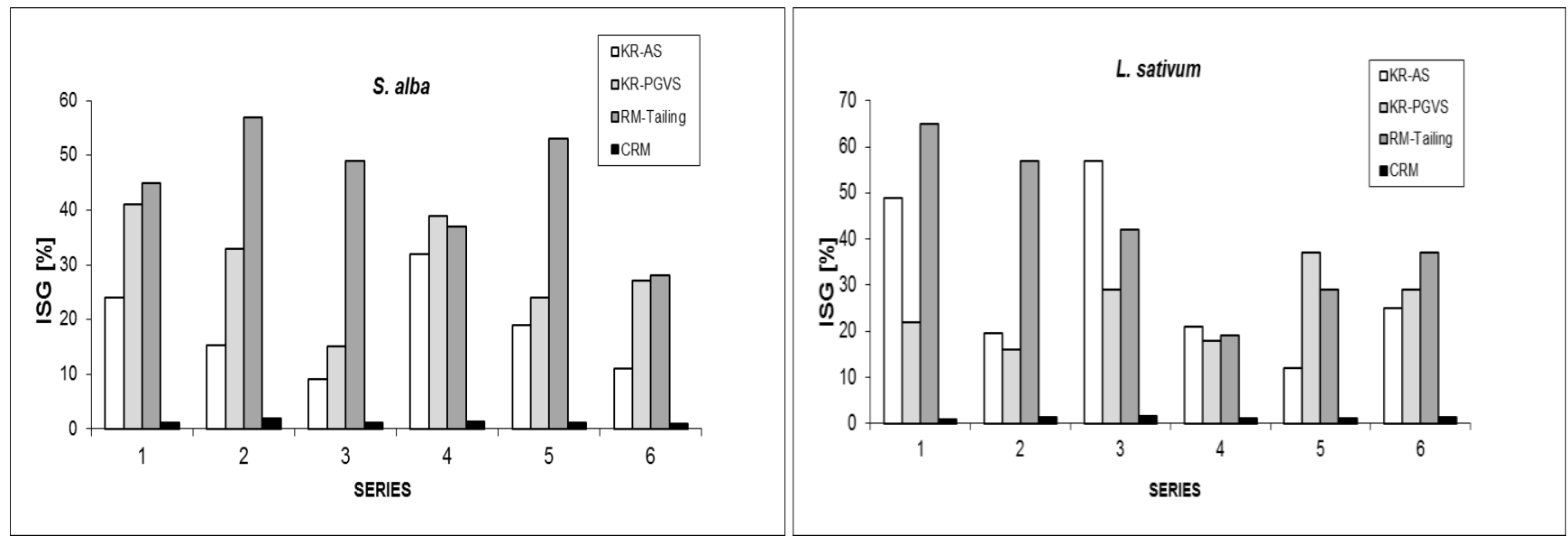

Fig. 1. Index of inhibition in seed germination (ISG, in \%) of Sinapis alba and Lepidium sativum in the six series of the soil samples, Krompachy soils (KR-AS and KR-PGVS), Rudňany tailing soils (RM-Tailing) and Control reference sample (CRM). Data represent average of $n=5$.

accumulation rate (Valerio et al. 2007; Fu et al. 2019). Fargašová (1999) reported a strong antagonistic effect between $\mathrm{Ni}$ and elements like $\mathrm{Mo}, \mathrm{Cu}, \mathrm{Mn}$, and described a significant stimulatory effect on $S$. alba seedlings cultivated hydroponically.

The potential toxicity data were described by the use of the toxicity classification system proposed by Persoone et al. 2003. The Control reference sample (CRM) belonged to Class I (No acute hazard).All soil samples (KR-As and KR-PGVS) belonged to Classes II (Slight acute hazard) and soil samples (RM-tailing) belonged to Classes III (Acute hazard). This sample are characterized by a very high total concentration of heavy metals $(\mathrm{Cu}, \mathrm{Ni}, \mathrm{As}$ and $\mathrm{Hg})$.

The results of the avoidance percentages of Dendrobaena veneta for three tested soil are shown in Fig. 3. Avoidance tests with earthworms were controlled by dual combinations of each test soil $v s$. the corresponding reference soil. The test was performed in a two chamber system. Soils were not acutely lethal to earthworms. The distribution of the worms found in the double control was within the range $10-40 \%$ for soils from KR-AS, while from KR-PGVS locality they were $40-80 \%$ after $48 \mathrm{~h}$. On the contrary, significant $(P<0.05)$ avoidance by $D$. veneta was $80-100 \%$ in soils from Rudňany-tailing. The habitat soils function was controlled to be limited if less than $20 \%$ of the organisms (on average) were found in the soil. This indicates an impact on properties and deputizes the "habitat function'. Soils of limited function are where $80 \%$ of the total animals are found in the control soil and $20 \%$ in the polluted soil (Latha and Basha 2019). Behaviour is a final integrated result of sensory, hormonal and metabolic processes.

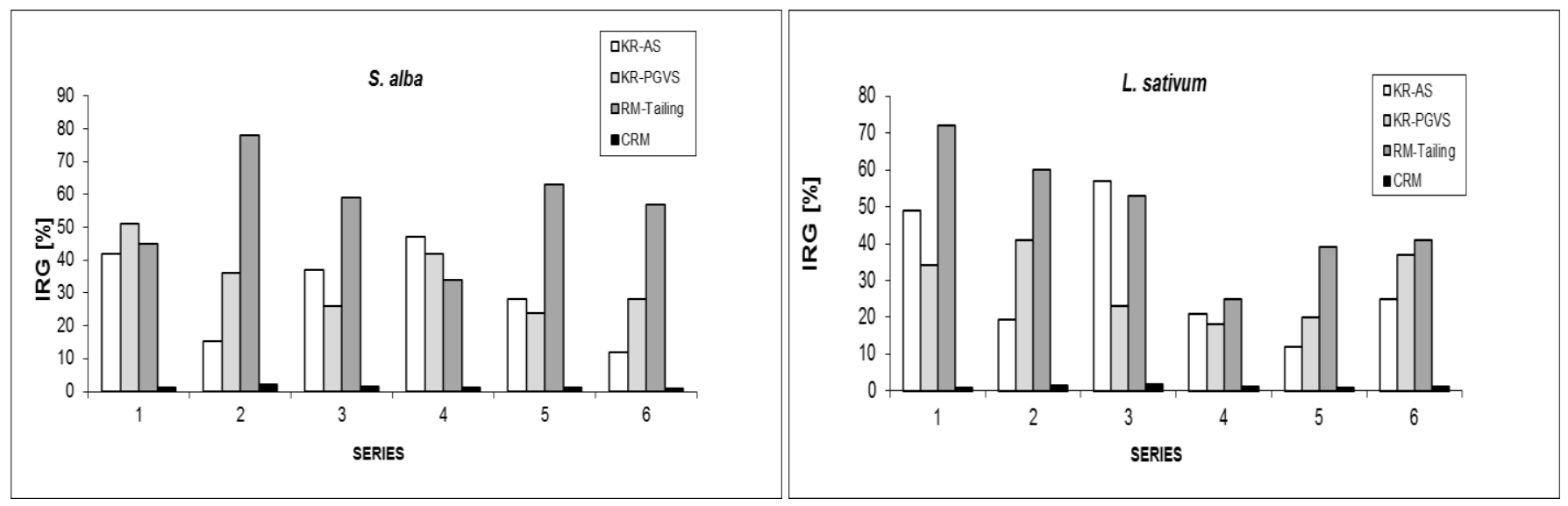

Fig. 2. Index of root growth inhibition (IRG, in \%) of the Sinapis alba and Lepidium sativum in the six series of the soil samples, Krompachy soils (KR-AS and KR-PGVS), Rudňany tailing soils (RM-Tailing) and Control reference sample (CRM). Data represent average of $n=5$. 


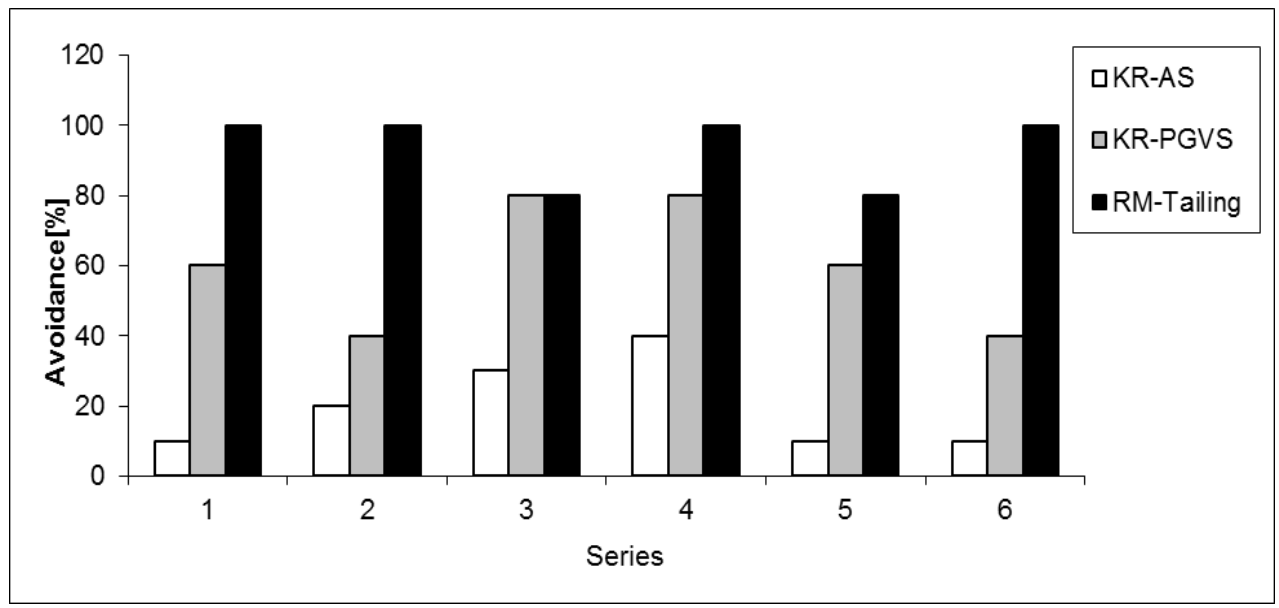

Fig. 3. Avoidance responses of the earthworm (D. veneta) in the six series of three different soil samples, Krompachy soils (KR-AS and KR-PGVS), and Rudňany tailing soils (RMTailing). Data represent average of $n=5$.
The habitat function of soil is involved in the interaction with biotic and abiotic components of the environment (Maity et al. 2018). In our case, when we compared all the results of the used bioassays, we obtained agreement in the evaluations so that the highest soil ecotoxicity was demonstrated in soil from Rudňany-Markušovce Tailling. Capowiez et al. (2006) suggests that behaviour seems to be a promising (efficiency) biomarker in earthworm studies, as it may give various endpoints which can perhaps be linked to soil functioning. Avoidance response tests reflect this behaviour of the earthworms, which works on the principle of preference or avoidance of substrates after a specific exposure period. The sensory cells in the epithelium of mouth region enable the earthworms to avoid adverse habitats (Stephenson et al. 1998). According to Manzo et al. (2014) a larger tests number with higher sensitivity together with a tailored weights attribution to endpoints and matrices would improve the final site evaluation. The results show that earthworm avoidance behaviour is an ecologically relevant parameter for assessing toxic metal spiked soils. Information combining from screening methods oriented on ecological receptors at risk by using available chemical methods and ecotoxicity tests have great benefit for further research of metal-contaminated sites. Advantage of combined methods is that the results can be compared and statistical analyzed together and so it is better to estimate the risk of ecosystems contamination. Thus, the tools of combined screening with environmental risk assessment in a certain area should be able to indicate effects, but also rapid, easy to apply and cheap (Semenzin et al. 2008).

\section{Conclusions}

To human health and other organisms the heavy metals contaminated soils are one of the environmental issues considered to be a serious threat. The toxicity and metal bioavailability were studied in soils from Krompachy and RudňanyMarkušovce in Eastern Slovakia. Average $\mathrm{Cu}, \mathrm{Ni}$, $\mathrm{Hg}$ and As concentrations are well above the limit levels, defining the need to apply a risk assessment procedure in order to determine and quantify potential environmental risks both to ecosystems. All soil samples from Krompachy locality belonged to slight acute hazard (Classes II) and soil samples from Rudňany-Markušovce (RM-tailing) belonged to acute hazard (Classes III). The abundance of the worms found in the double control was within the range of $10 \%-40 \%$, and for the soils from Krompachy it was $40 \%-80 \%$ after $48 \mathrm{~h}$. On the contrary, significant $(P<0.05)$ avoidance by $D$. veneta of $80 \%-100 \%$ was estimated in the soils RM-tailing. The results of the used bioassays coincided and pointed to the highest soil ecotoxicity soil from Rudňany-Markušovce tailing. Toxicity tests allowed us to carry out a preliminary screening of the contaminated areas ecotoxicological risk. The obtained results show that the Phytotoxkit test with Sinapis alba and Lepidium sativum, and avoidance test with earthworms (Dendrobaena veneta) can be considered as suitable tools in the soil contamination screening evaluation. 


\section{Acknowledgments}

This research was funded by the Slovak Grant Agency for the VEGA (grant No. 2/0165/19).

\section{Conflict of Interest}

The authors declare that they have no conflict of interest.

\section{References}

Aldaya MM, Lors Ch, Salmon S, Ponge J-F (2006) Avoidance bio-assays may help to test the ecological significance of soil pollution. Environ. Pollut. 140: 173180.

Angelovičová L, Bobul'ská L, Fazekašová D (2015) Toxicity of heavy metals to soil biological and chemical properties in conditions of environmentally polluted area middle Spiš (Slovakia). Carpath. J. Earth Environ. Sci. 10: 193-201.

Bravo S, García-Ordiales E, García-Navarro FJ, Amorós JA, Pérez-de-los-Reyes C, Jiménez-Ballesta R, Esbrí JM, García-Noguero EM, Higueras P (2019) Geochemical distribution of major and trace elements in agricultural soils of Castilla-La Mancha (central Spain): Finding criteria for baselines and delimiting regional anomalies. Environ. Sci. Pollut. Res. 26: 3100-3114.

Capowiez Y, Berard A (2006) Assessment of the effects of imidacloprid on the behavior of two earthworm species (Aporrectodea nocturna and Allolobophora icterica) using 2D terraria. Ecotox. Environ. Saf. 64: 198-206. content of substances and content of water.

Czerniawska-Kusza I, Kusza G (2011) The potential of the Phytotoxkit microbiotest for hazard evaluation of sediments in eutrophic freshwater ecosystems. Environ. Monit Assess. 179: 113-121.

Das KS, Chakrapani GJ (2011) Assessment of trace metal toxicity in soils of Raniganj Coalfield, India. Environ. Monit. Assess. 177: 63-67.

Davies NA, Mark EH, Stuart B (2003) Is the OECD acute worm toxicity test environmentally relevant? The effect of mineral form on calculated lead toxicity. Environ. Pollut. 121: 49-54.

Demková L, Ježný T, Bobul'ská L (2017) Assessment of soil heavy metal pollution in a former mining area - Before and after the end of mining activities. Soil Water Res. 12: 229-236.

Fargašová A (1999) Determination of metal interactions on root growth of Sinapis alba seedling. Biol. Plant. 42: 637-640.

Fu S, Wei Ch, Xiao Y, Li L, Wu D (2019) Heavy metals uptake and transport by native wild plants: implications for phytoremediation and restoration. Environ. Earth Sci. 78: 103.

Garcia-Lorenzo ML, Martinez-Sanchez MJ, Perez-Sirvent C, Molina J (2009) Ecotoxicological evaluation for the screening of areas polluted by mining activities. Ecotoxicology 18: 1077-1086.
Günter P, Pestemer W (1990) Risk assessment for selected xenobiotics by bioassay methods with higher plants. Environ. Manag. 14: 381-388.

Hredzák S, Dolinská S, Znamenáčková I, Lovás M, Šestinová O (2019) Possibilities of siderite and barite concentrates preparation from tailings of settling pit nearby Markušovce village (Eastern Slovakia). Inzynieria Miner. 20: 19-24.

Hronec O, Vilček J, Tóth T, Andrejovský P, Adamišin P, Andrejovská A, Daňová $M$, Huttmanová E, Vilmová $M$, Škultéty P, Juhasová M (2008) Heavy metals in soils and plants of Rudansko-Gelnicka loaded area. Acta Reg. Environ. 1: 24-28.

Hund-Rinke K, Achazi R, Römbke J, Warnecke, D (2003) Avoidance test with Eisenia fetida as indicator for the habitat function of soils: Results of a laboratory comparison test. J. Soils Sediments 3: 7-12.

ISO (2008) Soil quality - Avoidance test for testing the quality of soils and the toxicity of chemicals-test with earthworms (Eiseniafetida). ISO 17512-1, International Organization for Standardization, Geneva.

Jakabský Š, Karoli A, Hredzák S, Lovás M, Znamenáčková I (2010) Possibilities of processing and utilization of tailing from the settling pit near by Rudňany village (eastern Slovakia). Miner. Slov. 42: 305-308.

Kučerová G, Majzlan J, Lalinská-Voleková B, Radková A, Bačík P, Michňová J, Šotník P, Jurkovič L, Klimko T, Steininger R, Göttlicher J (2014) Mineralogy of neutral mine drainage in the tailings of siderite- $\mathrm{Cu}$ ores in eastern Slovakia. Can. Mineral. 52: 779-798.

Latha V, Basha PM (2019) Avoidance response in three ecologically different earthworm species exposed to heavy metal spiked soils of $\mathrm{Cr}$ and $\mathrm{Zn}$ : A comparative study. Int. J. Sci. Eng. Res. 10: 532-538.

Law No.220/2004, Supp. 2, on the Protection and Use of Agricultural Land and on the Amendment to Act no. 245/2003 Coll. on Integrated Prevention and Control of Environmental Pollution, Slovak Republic.

Loureiro S, Soares AMVM, Nogueira AJA (2005) Terrestrial avoidance behaviour tests as screening tool to assess soil contamination. Environ. Pollut. 138: 121-131.

Lukkari T, Teno S, Vaisanen A, Haimi J (2006) Effect of earthworms on decomposition and metal availability in contaminated soil: Microcosm studies of populations with different exposure histories. Soil Biol. Biochem. 38: 359-370.

Maity S, Poráčová J, Dey P, Vašková J, Vaško L, Sedlák V, Mydlárová, Blaščáková M (2018) Antioxidant responses in the earthworm Aporrectodea caliginosa of eastern Slovakia: application of principal component analysis as a tool to identify metal contaminated areas. Environ. Monit. Assess. 190: 1-16.

Manzo S, Schiavo S, Aleksi P, Tabaku A (2014) Application of a toxicity test battery integrated index for a first screening of the ecotoxicological threat posed by ports and harbors in the southern Adriatic Sea (Italy). Environ. Monit. Assess. 186: 7127-7139.

Nannoni F, Rossi S, Protano G (2014) Soil properties and metal accumulation by earthworms in the Siena urban area (Italy), Appl. Soil Ecol. 77: 9-17. 
STN EN 12879 Determination of loss when burning solids.

STN EN 75791 Determination the total content of substance and content of water.

OECD 207 Earthworm, acute toxicity tests. Guidelines for testing of chemicals. Organization for Economic Cooperation and Development, Paris.

OECD 208 Terrestrial Plant Test: Seedling Emergence and Seedling Growth Test. Determination of the effects of pollutants on soil flora: Effects of contaminated soil on the emergence and early growth of higher plants.

Persoone G, Marsalek B, Blinova I, Torokne A, Zarina D, Manusadzianas L, Nalecz-Jawecki G, Tofan L, Stepanova N, Tothova L (2003) A practical and user-friendly toxicity classification system with microbiotests for natural waters and wastewaters. Environ. Toxicol. 18: 395-402.

Phytotoxkit (2004) Seed germination and early growth microbiotest with higher plants. Standard operational procedure, Nazareth: MicroBioTests Inc. Belgium.

Semenzin E, Critto A, Rutgers M, Marcomini A (2008) Integration of bioavailability, ecology and ecotoxicology by three lines of evidence into ecological risk indexes for contaminated soil assessment. Sci. Total Environ. 389: 71-86.

Stephenson GL, Kaushik A, Kaushik NK, Solomon KR, Steele T, Scroggins RP (1998) Use of an avoidanceresponse test to assess the toxicity of contaminated soils to earthworms. In Sheppard CS et al. (Eds.), Advances in earthworm ecotoxicology, SETAC PRESS, Pensacola, USA, pp. 67-81.
Šestinová O, Findoráková L (2017) Assessment of Eastern Slovakia sediments genotoxicity and phytotoxicity using screening tests: Chromotests and Phytotoxkit. Fresenius Environ. Bull. 26: 2454-2462.

Šestinová O, Hančulák J, Dolinská S, Findoráková L, Špaldon T (2019a) Study of mercury behavior and earthworm bioassays in three solid environment components from selected areas of Eastern Slovakia. Glob. NEST J. 21: 484-489.

Šestinová O, Hančulák J, Špaldon T (2019c) Earthworms as useful bioindicator of soils contamination around Košice city, Slovakia. Nova Biotechnol. Chim. 18: 10-17.

Šestinová O, Hančulák J, Špaldon T, Gešperová D (2019b) Mobility behavior and environmental implications of trace elements associated with suburban soils from the steel industry. In IOP Conference Series: Earth and Environmental Science: $5^{\text {th }}$ World Multidisciplinary Earth Sciences Symposium, WMESS 2019, Prague, 362/1, pp. 1-8.

Valerio ME, Garcia JF, Peinado FM (2007) Determination of phytotoxicity of soluble elements in soils, based on a bioassay with lettuce (Lactuca sativa L.). Sci. Total. Environ. 378: 63-66.

Vasseur L, Fortin MJ, Cyr J (1998) Clover and cress as indicator species of impacts from limed sewage sludge and landfill waste waterland application. Sci. Total. Environ. 217: 231-239.

Wang W (1991) Literature review on higher plants for toxicity testing. Water Air Soil Pollut. 59: 231-239. 